\title{
Wild Boar Hepatitis E Seroprevalence in Hunting Funds from Buzău and Galaţi Counties
}

\author{
Daniela POREA*, Adriana ANITA, Anca PASLARU, Gheorghe SAVUTA \\ ${ }^{1}$ Department of Public Health, Faculty of Veterinary Medicine, University of Agricultural Sciences and \\ Veterinary Medicine, Mihail Sadoveanu Alley no 8, zip code 700489, Iasi, Romania. \\ * Corresponding author: daniela.porea@yahoo.com
}

Bulletin UASVM Veterinary Medicine 73(1) / 2016,

Print ISSN 1843-5270; Electronic ISSN 1843-5378

DOI:10.15835/buasvmcn-vm: 11506

\begin{abstract}
Hepatitis E virus (HEV) is the causal agent of the hepatitis E transmitted primarily via the faecal-oral route. HEV belongs to the family Hepeviridae, with HEV strains isolated from human and swine classified into the Orthohepevirus genus Orthohepevirus A species. The disease is considered as an emerging zoonosis with worldwide distribution based on recent advances showing that HEV strains circulating in domestic and wild pigs are genetically related to strains identified in autochthonous human cases.

The aim of the present study was to determine the seroprevalence of HEV in wild boar from Galaţi and Buzău counties, as a preliminary stage of the evaluation of the HEV distribution in wild boar population completed by molecular identification and characterization

Serum samples were collected from 68 wild boars during the hunting season, between December 2014 and February 2015, in 33 hunting funds from two Romanian Counties: Galați and Buzău. For serological analysis all samples were tested using a commercially available HEV antibody assay: ID Screen® Hepatitis E Indirect Multispecies ELISA kit (IDVet Diagnostics, France).

HEV antibodies have been detected in 7 out of 68 serums, representing an overall prevalence of $10.29 \%$. Seropositive animals were identified in both counties, respectively 3 out of $30(10 \%)$ for Buzău County and 4 out of $38(10.52 \%)$ in Galați County. The prevalence rates determined in this study are comparable to those determined in other European Countries.

Our results provided premises to investigate the hepatitis E virus presence in Romanian wild boar as well as in other wild animals, which are considered as potential HEV reservoirs.
\end{abstract}

Keywords: ELISA, hepatitis E, wild boar

\section{INTRODUCTION}

Hepatitis E virus (HEV) is an important human pathogen with a worldwide distribution, responsible for acute hepatitis. The disease is currently considered as an merging zoonosis (Franco et al., 2013). HEV is classified in the family Hepeviridae. HEV strains isolates from human and swine have been classified into the Orthohepevirus genus Orthohepevirus A species (Smith et al., 2014). HEV is a non-enveloped virus with a positive-orientated, single-stranded RNA genome with an outer diameter of approximately 27-34 $\mathrm{nm}$ and three open reading frames (ORFs), which code for the non-structural proteins (ORF1), the capsid protein (ORF2) and a phosphoprotein that is associated with the cytoskeleton (ORF3) (Zafrullah et al., 1997).

Four genotypes of HEV have been differentiated (HEV-1 to HEV-4): HEV-1 and HEV-2 infect exclusively humans while HEV-3 and HEV4 can infect humans, pigs and other mammals. All HEV isolates derived from wild boars and a number of other animal species belong to HEV-3 and HEV-4. Genotypes HEV-3 has been detected in wild boars population from Europe countries (Pavio et al., 2010). Importantly, HEV seems to circulate asymptomatically in pigs and result in a subclinical course of infection with only mild 
microscopic lesions in the liver and associated lymph nodes. This sustain the hypothesis that HEV infection may commonly be subclinical in wild boar (Meng et al., 1997).

Initially, hepatitis E was considered to be a travel-associated disease in Western countries but recent advances has shown that HEV strains circulating in domestic and wild pigs are genetically related to strains identified in autochthonous human cases (Pavio et al., 2015). Autochthonous humans cases of HEV have been reported in industrialized countries such as Japan, Spain, Italy, the United States, and France (Mansuy et al., 2004; Renou et al., 2007).

Domestic pigs and wild boars have been recognized as the main animal reservoirs of zoonotic HEV. Studies on anti-HEV antibodies detection in people working in contact with swine or wild boar suggests animal to human transmission of the virus (Galiana et al., 2008). In Italy, one of the risk factors for HEV infection in humans is the exposure to wild boars (La Rosa et al., 2011). In a case-control study in Germany, boar organs and meat consumption was positively associated with HEV infection (Wichmann et al., 2008). These data imply that wild boar is an important source of HEV infection in humans.

The first indications of HEV-infections in wild boar was in 1999, when serological examinations of wild boars found anti-HEV antibodies in $17 \%$ of investigated free-living pigs (Chandler et al., 1999). The high HEV seroprevalence of anti-HEV antibodies in this species was reported in several European countries including the Germany (Kaci et al., 2008), Spain (de Deus et al., 2008b) , Italy (Martelli et al., 2008), Sweden (Widén et al., 2011), Hungary (Reuter et al., 2009) and the Netherlands (Rutjes et al., 2010). The first wild boar HEV was detected in Japan (Sonoda et al., 2004). Adlhoch et al. (2009b) reported the highest HEV RNA rate detected, 68.2\%, in wild boars population from Germany.

In Romania the data available regarding hepatitis E virus infection are limited. As for the researches on wild boar, serological investigations were conducted in two counties: Iași and Buzău (Aniță et al., 2009; Botezatu et al., 2014).

\section{MATERIALS AND METHODS}

Serum samples from 68 wild boars were collected during the hunting season, between
December 2014 and February 2015, in 33 hunting funds from two Romanian Counties: 15 from Buzău County (30 samples) and 18 from Galați County (38 samples), for serological surveillance. The age distribution of wild boars from Galați County was: less than 1 year $(n=2)$, between 1 and 2 years $(n=26)$, older than 2 years $(n=10)$. The age of wild boars from Buzău County could not be determined. The sera had been stored at $-20^{\circ} \mathrm{C}$ until use.

The presence of HEV specfic antibodies was evaluted using a commercially available HEV antibody assay: ID Screen ${ }^{\circledR}$ Hepatitis E Indirect Multi-species ELISA kit, based on recombinant capsid protein of HEV genotype 3 (IDVet Diagnostics, Montpellier, France) according to the manufacturer' $s$ instruction. The fact that it is based on a recombinant capsid protein of genotype 3 - the HEV genotype that has actually been demonstrated to infect pigs - demonstrates the specificity and sensitivity of the test. Numbered wells of the microplates were coated with a recombinant HEV genotype 3 capsid protein expressed in baculovirus and affinity purified. The odd - numbered wells were uncoated. The kit conjugate reacts against swine, wild boar, ruminant and human IgG.

The sera were diluted 1:20 with dilution buffer before adding to the test plates and were incubated 45 minutes at room temperature. After washes, a multi-species horseradish peroxidase (HRP) conjugate was added for 30 minutes at room temperature. It fixes to the anti-HEV antibodies, forming an antigen - antibody - conjugate - HRP complex. Plates were washed, and the substrate (TMB) was added. After 15 minutes the reaction was blocked by adding the stop solution. The optical density (O.D.) was measured at $450 \mathrm{~nm}$.. The results were interpreted by calculation of the $\mathrm{S} / \mathrm{P}$ percentage = corrected O.D. of sample/ corrected O.D. of positive control $\mathrm{x}$ 100. The samples presenting $\mathrm{S} / \mathrm{P} \geq 70 \%$ were considered positive, $\mathrm{S} / \mathrm{P}$ between $60 \%$ end $70 \%$ doubtful and $\mathrm{S} / \mathrm{P} \leq 60 \%$ - negative.

\section{RESULTS AND DISCUSSIONS}

In this study, we investigated the presence of HEV antibodies using a Indirect ELISA in order to determine the seroprevalence of HEV infection in wild boar population in 33 hunting funds from two Romanian Counties: Galați and Buzău. HEV 
antibodies were detected in 7 (prevalence 10,29\%; $95 \% \mathrm{CI}, 2.94-17.5$ ) of the 68 serums samples tested. The obtained data show that seropositive animals are present in both Counties, respectively 3 out of 30 (prevalence 10\%; 95\%CI, $0.44-20.6$ ) for Buzău County and 4 out of 38 (prevalence 10,52\%; 95\% CI, 2.94 - 17.5) in Galați County (Tab. 1), but not are present in all hunting funds investigated.

In Buzău County, the distribution of positive samples in the hunting funds where the samples was tested and where HE antibodies was detected is: 1 out of 1 for hunting fund 42 -Berca and hunting fund 54 - Săgeata, 1 out of 3 in hunting fund 41 - Vintilă Vodă (Fig. 1). The seroprevalence rates determined in this study (10\%) are comparable to those obtained by Botezatu et al. (11.39\%), the presence of HEV antibodies being identified in wild boar in the same geographical regions (hunting funds Vintilă Vodă and Berca). This suggests that HEV is prezent in wild boar population from Buzău County.

In Galati County, the distribution of positive samples in the hunting funds where samples was tested and where HE antibodies was detected is: 2 out of 5 in hunting fund 30 - Suceveni and 2 out of 4 in hunting fund 15 - Barcea (Fig. 2). The present study is the first report on the prevalence of HEV antibodies in wild boar population from Galați County.

The HEV seropositivity was detected in wild boar aged between 1 and 2 years (prevalence $3,84 \%, 95 \% \mathrm{CI},-3.90-11.59$ ) and in animals older than 2 year (prevalence 30\%; 95\% CI, -2.8 - 62.28) (Tab. 2). In studies conducted by Sonoda et al. (2004) and Nishizawa et al. (2005) in Japan, was also reported HEV infection more frequently in wild boars of approximately 2 years old. This

Tab. 1. Seroprevalence of HEV infection in wild boar population from Buzău and Galați Counties

\begin{tabular}{cccc}
\hline County & No. of animals tested & $\begin{array}{c}\text { No. of positive } \\
\text { animals }\end{array}$ & $\begin{array}{c}\text { Seroprevalence (\%) } \\
{[95 \% \mathrm{CI}]}\end{array}$ \\
\hline Buzău & 30 & 3 & $10 \%[-1.18-21.18]$ \\
\hline Galați & 38 & 4 & $10,52 \%[0.44-20.6]$ \\
\hline Total & $\mathbf{6 8}$ & $\mathbf{7}$ & $\mathbf{1 0 , 2 9 \% [ 2 . 9 4 - 1 7 . 5 ]}$ \\
\hline
\end{tabular}

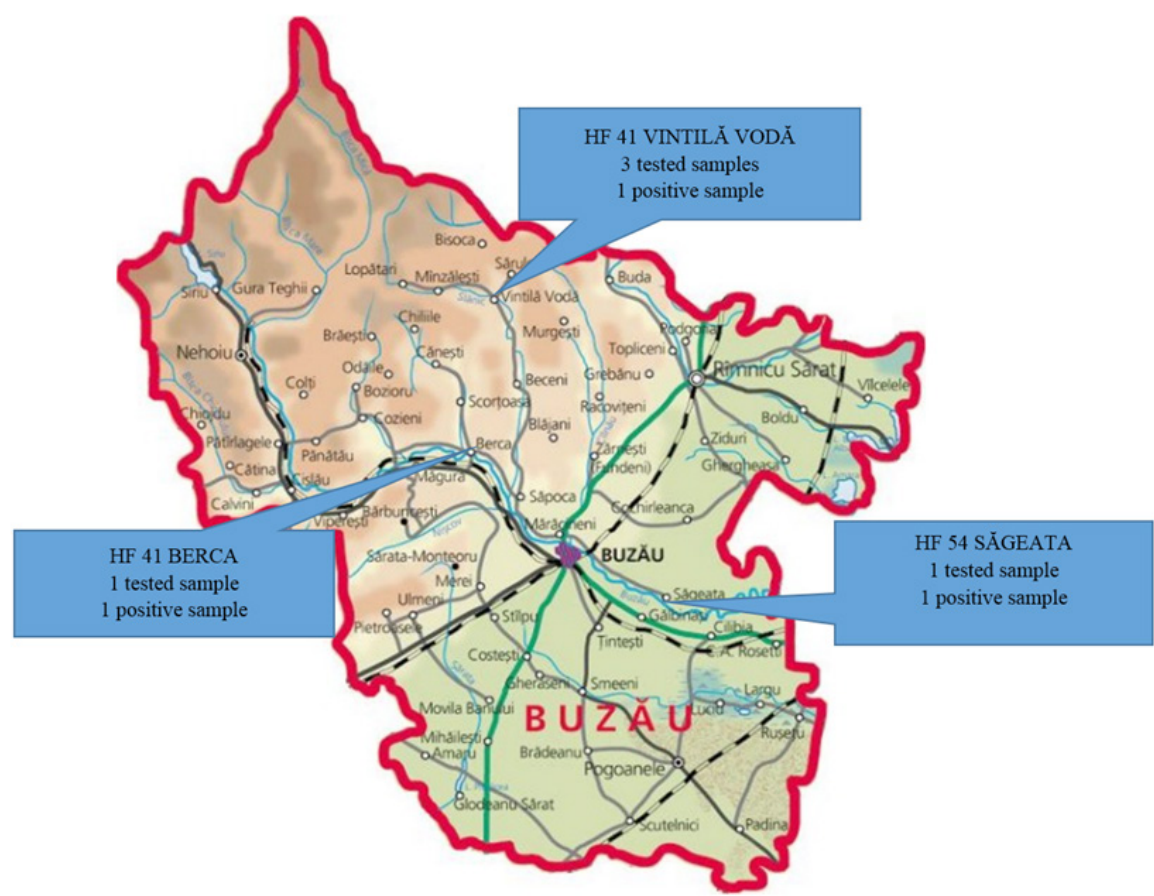

Fig. 1. Distribution of the HEV seropositive wild boar from Buzău County 
data might suggest that infection in wild boar can become chronic and possibly associated by an incompletely protective immunity.

The seroprevalence rate did not vary greatly within the analyzed Counties. This prevalence is generally higher than that reported in other studies on wild boars. Anita et al., 2009, reported a prevalence of $4,44 \%$ in a sample of 90 wild boars by use of different available HEV antibody assay. Differences in determined prevalences may be explained by the ecology of the wild boar populations (density of the population and environmental characteristics) and sustain that future research on the prevalence of HEV in wild boar populations from Romania are needed.

Several European countries reported high seroprevalences in this species including the Spain $(42,7 \%)$, France (14\%), and Germany (14\%) (de Deus et al., 2008; Carpentier et al., 2012; Adlhoch et al., 2009).
The present study revealed that the wild boars might represent one of the reservoirs of HEV in Romania, but the information with situation of HEV infection in Romania are limited and epidemiological correlations between HEV in wild boar and domestic pigs were not investigated. In 2014, Aniță et al., reported HEV circulation in pig farms based on phylogenetic analysis of the ORF2 sequence indicating that the Romanian swine HEV isolates belonged to genotype 3. Further epidemiological studies are needed for the analysis of wild boar isolates as HEV reservoir for other animals and for humans.

\section{CONCLUSIONS}

The results of our study indicated the presence of HEV in wild boar population from South East Romania Also, we appreciate that the virus may be circulating throughout the study area, taking in account the movement of wild boar populations.

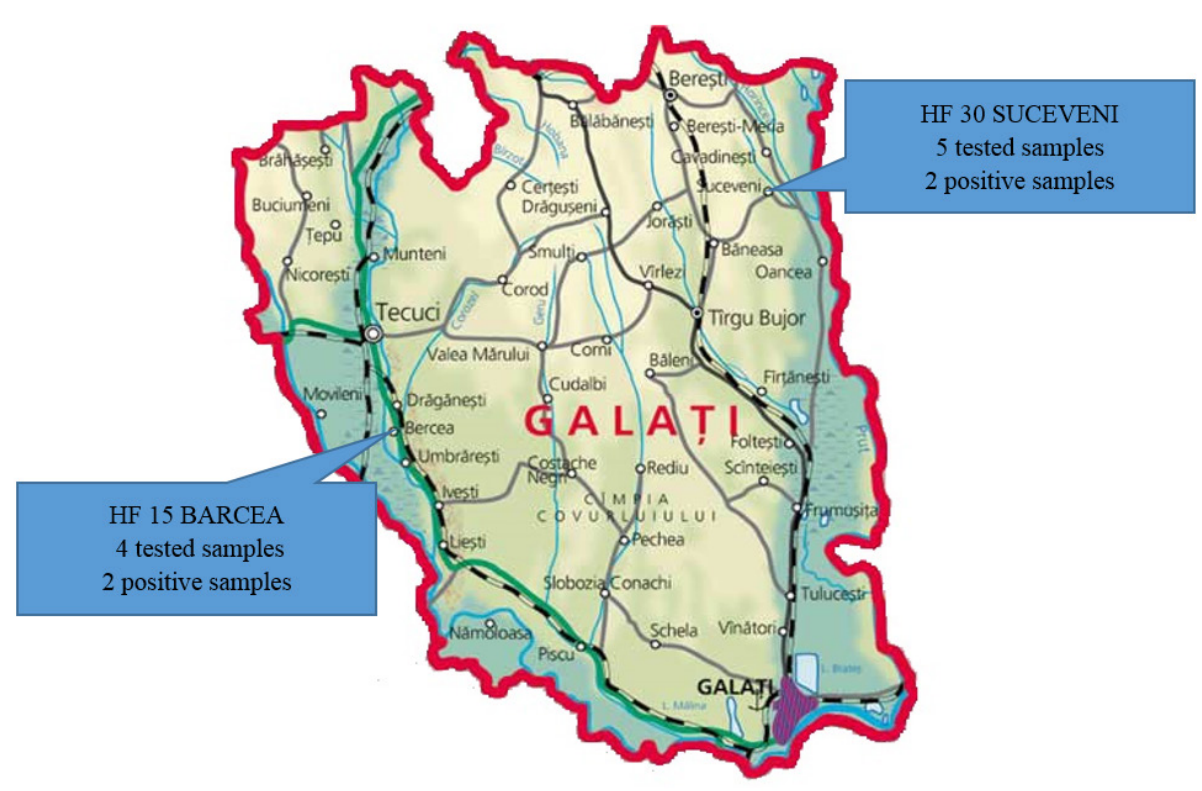

Fig. 2. Distribution of the HEV seropositive wild boar from Galați County

Tab. 2. Distribution by age of the HEV positive wild boars in Galați County

\begin{tabular}{cccc}
\hline Age class & $\begin{array}{c}\text { No. of animals } \\
\text { tested }\end{array}$ & $\begin{array}{c}\text { No. of positive } \\
\text { animals }\end{array}$ & $\begin{array}{c}\% \text { positivity } \\
{[95 \% \mathrm{CI}]}\end{array}$ \\
\hline$<1$ year & 2 & 0 & $0 \%$ \\
\hline 1-2 year & 26 & 1 & $3,84 \%[-3.90-11.59]$ \\
\hline$>2$ year & 10 & 3 & $30 \%[-2.8-62.28]$ \\
\hline
\end{tabular}


Given the zoonotic risk of the HEV, further investigations aimed to evidence the hepatitis $\mathrm{E}$ virus presence in Romanian animals, which are considered as potential HEV reservoirs for human, are required.

\section{REFERENCES}

1. Adlhoch C, Wolf A, Meisel H, Kaiser M, Ellerbrok H, Pauli G (2009b). High HEV presence in four different wild boar populations in East and West Germany. Vet Microbiol 139:270-278.

2. Aniță A, Aniță D, Tănase OI, Ludu L, Savuța G (2009). Serological evidence of hepatitis $\mathrm{E}$ virus infection in different swine categories from Iaşi County. Lucrări Ştiinţifice - Medicină Veterinară Iași 52,11(2): 817-819.

3. Aniţă A, Gorgan L, Aniţă D, Oşlobanu L, Pavio N, Savuța G (2014). Evidence of hepatitis E infection in swine and humans in the East region of Romania. International Journal of Infectious Diseases 29:232-237.

4. Botezatu C, Tănase O, Anița A, Rîmbu C, Carp-Cărare M (2014). Studies regarding antibodies prevalence to selected viral pathogens from wild boars. Lucrari Științifice -Medicina Veterinara, Timișoara, 47(2):20-28.

5. Carpentier A, Chaussade H, Rigaud E, Rodriguez J, Berthault C, Boué F et al (2012). High hepatitis E virus seroprevalence in forestry workers and in wild boars in France. J Clin Microbiol 50:2888-2893.

6. Chandler JD, Riddell MA, Li F, Love RJ, Anderson DA (1999). Serological evidence for swine hepatitis E virus infection in Australian pig herds. Vet Microbiol 68:95-105.

7. de Deus N, Peralta B, Pina S, Allepuz A, Mateu E, Vidal D et al (2008b). Epidemiological study of hepatitis E virus infection in European wild boars (Sus scrofa) in Spain. Vet Microbiol 129:163-170.

8. Franco MR, Di Bartolo I, Ponterio E, Angeloni G, Trevisani M, Ostanello F (2013). Zoonotic transmission of hepatitis $\mathrm{E}$ virus in industrialized countries. New microbiologica 36: 331-344.

9. Galiana C, Fernandez-Barredo S, Garcia A, Gomez MT, Perez-Gracia MT (2008). Occupational exposure to hepatitis E virus (HEV) in swine workers. Am. J Trop Med Hyg 78: 1012-1015.

10. Kaba M, Brouqui P, Richet H, Badiaga S, Gallian P, Raoult D, Colson P (2011) Hepatitis E Virus Infection in Sheltered Homeless Persons, France. Emerging Infectious Diseases 16 (11): 1761-1763.

11. Kaci S, Nöckler K, Johne R (2008). Detection of hepatitis E virus in archived German wild boar serum samples. Vet Microbio 128:380-385.

12. La Rosa G, Muscillo M, Vennarucci VS, Garbuglia AR, La Scala P, Capobianchi MR (2011). Hepatitis E virus in Italy: molecular analysis of travel-related and autochthonous cases. J Gen Virol 92:1617-26.

13. Mansuy JM, Peron JM, Abravanel F, Poirson H, Dubois M, Miedouge M, Vischi F, Alric L, Vinel JP, Izopet J (2004).
Hepatitis E in the south west of France individuals who have never visited an endemic area. J Med Virol 74:419424.

14. Martelli F, Caprioli A, Zengarini M, Marata A, Fiegna C, Bartolo ID et al (2008). Detection of hepatitis E virus (HEV) in a demographic managed wild boar (Sus scrofa scrofa) population in Italy. Vet Microbiol 126:74-81.

15. Meng X J, Purcell R H, Halbur PG, Lehman JR, Webb DM, Tsareva TS, Haynes JS, Thacker BJ, Emerson SU (1997). A novel virus in swine is closely related to the human Hepatitis E virus. Proc Natl Acad Sci USA 94:9860-98650.

16. Nishizawa TM, Takahashi K, Endo S, Fujiwara N, Sakuma F, Kawazuma $\mathrm{H}$ et al (2005). Analysis of the full-length genome of hepatitis E virus isolates obtained from wild boars in Japan. J Gen Virol 86:3321-3326.

17. Pavio N, Meng XJ, Doceul V (2015). Zoonotic origin of hepatitis E. Current Opinion in Virology 10:34-41.

18. Pavio N, Meng XJ, Renou C (2010). Zoonotic hepatitis E: animal reservoirs and emerging risks. Vet Res 41:46.

19. Renou C, Cadranel JF, Bourliere M, Halfon P, Ouzan D, Rifflet $\mathrm{H}$ et al (2007). Possible zoonotic transmission of hepatitis E from pet pig to its owner. Emerg Infec Dis 13:1094-6.

20. Reuter G, Fodor D, Forgách P, Kátai A, Szucs G (2009). Characterization and zoonotic potential of endemic hepatitis E virus (HEV) strains in humans and animals in Hungary. J Clin Virol 44:277-281.

21. Rutjes SA, Lodder-Verschoor F, Lodder WJ, van der Giessen J, Reesink H, Bouwknegt M, de Roda Husman AM (2010). Seroprevalence and molecular detection of hepatitis E virus in wild boar and red deer in The Netherlands. J Virol Methods 168:197-206.

22. Smith DB, Simmonds P, Jameel S, Emerson SU, Harrison TJ, Meng XJ et al (2014). Consensus proposals for classification of the family Hepeviridae. J Gen Virol.

23. Sonoda H, Abe M, Sugimoto T, Sato Y, Bando M, Fukui E et al (2004). Prevalence of hepatitis E virus (HEV) Infection in wild boars and deer and genetic identification of a genotype $3 \mathrm{HEV}$ from a boar in Japan. J Clin Microbiol 42:5371-5374.

24. Voiculescu M,Iliescu L, Ionescu C,Micu L, Ismail G,Zilișteanu D et al (2010). A Cross-Sectional Epidemiological Study of HBV, HCV, HDV and HEV Prevalence in the SubCarpathian and South-Eastern Regions of Romania. J Gastrointestin Liver Dis 19(1):43-48.

25. Wichmann O, Schimanski S, Koch J, Kohler M, Rothe C, Plentz A, Jilg W, Stark K (2008). Phylogenetic and casecontrol study on hepatitis E virus infection in Germany. J Infect Dis 198:1732-1741.

26. Widén F, Sundqvist L, Matyi-Toth A, Metreveli G, Belák S, Hallgren G, Norder H (2011). Molecular epidemiology of hepatitis $\mathrm{E}$ virus in humans, pigs and wild boars in Sweden. Epidemiol Infect 139:361-371.

27. Zafrullah M, Ozdener MH, Panda SK, Jameel S (1997). The ORF3 protein of hepatitis E virus is a phosphoprotein that associates with the cytoskeleton. J Virol 71:9045-9053. 